\title{
Molecular genetic identification of skeletal remains from the Second World War Konfin I mass grave in Slovenia
}

\author{
Irena Zupanič Pajnič • Barbara Gornjak Pogorelc • \\ Jože Balažic
}

Received: 7 August 2009 / Accepted: 10 February 2010 /Published online: 10 March 2010

(C) The Author(s) 2010. This article is published with open access at Springerlink.com

\begin{abstract}
This paper describes molecular genetic identification of one third of the skeletal remains of 88 victims of postwar (June 1945) killings found in the Konfin I mass grave in Slovenia. Living relatives were traced for 36 victims. We analyzed 84 right femurs and compared their genetic profiles to the genetic material of living relatives. We cleaned the bones, removed surface contamination, and ground the bones into powder. Prior to DNA isolation using Biorobot EZ1 (Qiagen), the powder was decalcified. The nuclear DNA of the samples was quantified using the realtime polymerase chain reaction method. We extracted 0.8 to $100 \mathrm{ng} \mathrm{DNA} / \mathrm{g}$ of bone powder from 82 bones. Autosomal genetic profiles and Y-chromosome haplotypes were obtained from $98 \%$ of the bones, and mitochondrial DNA (mtDNA) haplotypes from $95 \%$ of the bones for the HVI region and from $98 \%$ of the bones for the HVII region. Genetic profiles of the nuclear and mtDNA were determined for reference persons. For traceability in the event of contamination, we created an elimination database including genetic profiles of the nuclear and mtDNA of all persons that had been in contact with the skeletal remains. When comparing genetic profiles, we matched 28 of the 84 bones analyzed with living relatives (brothers, sisters, sons, daughters, nephews, or cousins). The statistical analyses showed a high confidence of correct identification for all 28 victims in the Konfin I mass grave (posterior probability ranged from $99.9 \%$ to more than $99.999999 \%$ ).
\end{abstract}

\footnotetext{
I. Zupanič Pajnič $(\bowtie) \cdot$ B. Gornjak Pogorelc $\cdot$ J. Balažic Institute of Forensic Medicine, Faculty of Medicine, University of Ljubljana,

Korytkova 2,

1000 Ljubljana, Slovenia

e-mail: irena.zupanic@mf.uni-lj.si
}

Keywords Forensic identification · Mass grave victims . STR $\cdot$ mtDNA $\cdot$ Second World War bones $\cdot$ Slovenia

\section{Introduction}

The ability to recover DNA from old bones has become a valuable tool for identifying victims in mass graves and individual graves from the Second World War. When working with DNA from old bones, the main problem stems from the low amount of starting molecules, degradation of DNA, and the presence of polymerase chain reaction (PCR) inhibitors [1]. MtDNA testing is regularly employed in forensic identification of aged skeletal remains [2-4], but mtDNA typing alone is often insufficient for identification, and the analysis of nuclear short tandem repeat (STR) loci is required [5]. The identification of the 50-year-old skeletal remains of pilot James B. McGovern [6] serves as a good example, because the presence of a common mtDNA control region type limited the discriminatory power of the mtDNA data, and it was only after analyses of autosomal STR loci and Y chromosomal STR loci (Y-STRs) were performed that the likelihood ratio (LR) reached a value that supported the hypothesis that the bone was from an individual related to the family references, rather than from an unrelated individual. However, due to the rather long time span since the Second World War massacres, it is difficult to find living relatives to identify the victims in mass graves. If there are no close relatives, more distant relatives can also be very helpful because a combination of genetic markers may provide satisfactory probabilities of identity.

Molecular genetic methods have been used to identify victims of massacres that took place during and after the Second World War (1945) in Slovenia [7-10] and Croatia [11], and also for Finnish soldiers that lost their lives in the 
former Soviet Union [4]. Because of differences in DNA preservation in skeletal remains due to regional climatic conditions and chemical properties of the soil, the studies vary in the number of genetic markers that researchers analyzed. Palo et al. [4] obtained mtDNA haplotypes from bones for the HVI/HVII regions and compared them to mtDNA haplotypes of living maternal relatives. Definis Gojanović et al. [11] obtained Y-STR haplotypes and compared them to Y-STR haplotypes of living paternal relatives. Marjanović et al. obtained autosomal STR profiles in one study [7] and Y-STR haplotypes in another [10]; they did not analyze the polymorphisms in the control region of mtDNA. In identifying Second World War victims from two mass graves, we obtained mtDNA haplotypes from the HVI/HVII regions, Y-STR haplotypes, and autosomal STR profiles from the bones, which made it possible to compare both close and distant relatives in both the maternal and paternal lines. Among the skeletal remains from a small mass grave at Mount Storžič, we identified three victims with posterior probability (PP) from $99.999 \%$ to $99.99999 \%$ $[8,9]$. This report discusses identification of skeletal remains from a large mass grave at the cave site Konfin I, where 88 victims were kild.

The Commission on Concealed Mass Graves in Slovenia has registered almost 600 hidden mass graves from the period during and after the Second World War [12]. For most mass graves, there are no documents to base victim identification on. The Konfin I mass grave is a rare exception because a list of the victims ( 88 Slovenian men taken from the Central Prison on the night of 24 June 1945 and brought to the execution site at Konfin I Cave) can be made based on archives (i.e., the prisoners' logbook of the Yugoslav secret police (OZNA) Central Prison and the registry of detainees with the list of wounded and patients). Among the victims were 40 wounded men and patients that had been transferred from the general hospital in Ljubljana to the OZNA Central Prison 14 days prior to execution and 48 men selected from among the prisoners. These men were not tried in a court and had not been convicted of any crime [13]. Their bodies were thrown into a 45-m-deep karst cave, and the entrance was dynamited. The bodies were not covered with earth that would have kept the skeletons in their original position. Water runoff ran unhindered into the cave, and its $20-\mathrm{m}^{2}$ bottom was completely covered with a 2-m-thick layer of mixed bones filled with mud.

The skeletal remains were excavated under the leadership of a local archeologist and anthropologist. Under a decree by the government of the Republic of Slovenia, the Commission on Concealed Mass Graves in Slovenia entrusted identification of the victims in the Konfin I mass grave to our institute. Thus, after excavation and anthropological study, the bones were sent to us to perform the molecular genetic identification. DNA typing involved all excavated right femurs (67 complete and 17 proximal fragments). We collected buccal swabs from 41 family references (sisters, brothers, daughters, sons, wives, cousins, and nephews) that were close or distant relatives of 36 Konfin I massacre victims. The bone samples for DNA analysis were collected, labeled, and photo documented. The bones were numbered; we used the same numbers as the anthropologist.

Typing of nuclear DNA and mtDNA was carried out for the bones, reference persons, and persons to be included in the elimination database. For reference persons, mtDNA typing was carried out for maternal relatives and Y-chromosome typing for paternal relatives.

\section{Materials and methods}

To ensure quality standards and prevent contamination in the molecular genetic laboratory, we followed recommendations by Alonso et al. [14], Tully et al. [15], Bär et al. [16], Carracedo et al. [17], Kemp and Smith [18], Wilson et al. [19], Kalmar et al. [20], Davoren et al. [21], Tamariz et al. [22], Shaw et al. [23], and Vanek et al. [24]. We created an elimination database containing all persons that had been in contact with the skeletal remains at any phase of excavation, storage, anthropological analysis, or molecular genetic analysis. The elimination database allows traceability in the case of contamination. The extractionnegative controls were included in every batch (usually 23 samples) of extraction to verify the purity of the extraction reagents. We performed at least two extractions for each bone, and together with the bones, we thus analyzed at least eight extraction-negative controls. The PCR-negative controls were included in every amplification reaction to verify the purity of the amplification reagents. The PCR-positive controls were also included in every amplification reaction. All negative and positive controls were carried through the sequencing process.

\section{DNA extraction}

We collected buccal swabs on sterile cotton swabs from living relatives and persons included in the elimination database. For genetic investigations, an 8- to $10-\mathrm{cm}$ fragment was taken from each bone. The bone samples were cleaned mechanically and chemically. The surface was decontaminated by physical removal of the surface using a rotary sanding tool (Dremel) and rinsing in 5\% Alconox detergent, water, and $80 \%$ ethanol. Grinding in a TissueLyser (Retsch) homogenizer using liquid nitrogen followed. Genomic DNA was obtained from $0.5 \mathrm{~g}$ of bone powder incubated in $1.5 \mathrm{ml}$ of $0.5 \mathrm{M}$ EDTA pH 8.3 (Promega) for $24 \mathrm{~h}$ at $37^{\circ} \mathrm{C}$ in a Thermomixer comfort (Eppendorf), shaken at $950 \mathrm{rpm}$. After centrifugation at $13,400 \mathrm{rpm}$ for $1.5 \mathrm{~min}$ in a MiniSpin 
(Eppendorf) centrifuge, the supernatant was discarded. The incubation of bone material in EDTA was repeated two more times. After $72 \mathrm{~h}$ of decalcification, the precipitate was washed with $1 \mathrm{ml}$ of ultrapure distilled water (Gibco) and centrifuged at 13,400 rpm for $1.5 \mathrm{~min}$, and the supernatant was discarded. Then, $250 \mu \mathrm{l}$ of G2 buffer and $60 \mu \mathrm{l}$ of proteinase K (both EZ1 DNA Investigator Kit, Qiagen) was added to the precipitate, and it was incubated overnight at $56^{\circ} \mathrm{C}$ in a Thermomixer comfort (Eppendorf), shaken at $950 \mathrm{rpm}$. This was followed by centrifugation at $6,000 \mathrm{rpm}$ for $4 \mathrm{~min}$ in a MiniSpin (Eppendorf) centrifuge. Up to $500 \mu \mathrm{l}$ of supernatant was transferred to the sample tube. The DNA was purified in a Biorobot EZ1 (Qiagen) device using the EZ1 DNA Investigator Card and EZ1 DNA Investigator Kit (Qiagen). Following the manufacturer's instructions [25], the Biorobot EZ1 was used to obtain genomic DNA from decalcified bone precipitate using the large-volume protocol, and from relatives' buccal swabs and elimination database samples using the "tip dance" protocol. The extractionnegative controls were included in the extraction process to verify the purity of extraction reagents. Genomic DNA extraction was carried out at least twice from each bone.

\section{DNA quantification}

DNA extracts from all samples were quantified, and levels of PCR inhibitors monitored, using the Quantifiler ${ }^{\mathrm{TM}}$ Human DNA Quantification Kit (Applied Biosystems). Reactions were carried out in an ABI PRISM 7000 Sequence Detection System (Applied Biosystems) using SDS software, version 1.0 (Applied Biosystems) according to the manufacturer's instructions [26]. From at least two isolates obtained from a single bone, the one with the highest nuclear DNA content was used for nuclear STR typing, and others were used for mtDNA sequencing. When less than $16 \mathrm{pg} \mathrm{DNA} / \mu \mathrm{l}$ was detected, autosomal and YSTR loci were amplified in parallel, and only duplicated alleles were reported.

\section{STR typing of nuclear DNA}

STR typing of autosomal DNA was performed for bones using various amplification kits: the AmpFlSTR Identifiler ${ }^{\mathrm{TM}}$ PCR Amplification Kit (Applied Biosystems), PowerPlex 16 System (Promega), and additionally, for degraded DNA samples, the AmpFlSTR MiniFilerTM PCR Amplification Kit (Applied Biosystems). The AmpFlSTR IdentifilerTM PCR Amplification Kit and PowerPlex 16 System contain the same 13 core STR loci and amelogenin, whereas the AmpFlSTR IdentifilerTM PCR Amplification Kit also contains the loci D2S1338 and D19S433, and the PowerPlex 16 System, the loci Penta E and Penta D. Overall, 17 STR loci and amelogenin were amplified. The AmpFlSTR MiniFilerTM
PCR Amplification Kit (Applied Biosystems) contains eight STR loci shared with the AmpFlSTR IdentifilerTM PCR Amplification Kit, but uses shorter amplicons, which makes them more likely to be successful on fragmented DNA. When statistical analysis did not reveal a PP of $99.9 \%$, the PowerPlex ESX 17 System (Promega) amplification kit was used to obtain the profiles on six additional STR loci (D10S1248, D1S1656, D22S1045, D2S441, D12S391, and SE33). Typing of the Y-STRs was performed using the AmpFlSTR YFiler PCR Amplification Kit (Applied Biosystems) to amplify 17 Y-STRs. All reactions were performed using the ABI PRISM 7000 Sequence Detection System (Applied Biosystems). For best performance of the AmpFlSTR IdentifilerTM PCR Amplification Kit (Applied Biosystems), the optimal amount of initial genomic DNA is 0.5 to $1.25 \mathrm{ng}$. For samples containing $>50 \mathrm{pg} / \mu \mathrm{l}$ DNA, PCR was performed according to the manufacturer's instructions [27], but bovine serum albumin (BSA; Sigma; final concentration $40 \mathrm{ng} / \mu \mathrm{l}$ ) was added, and a double amount of AmpliTaq Gold DNA Polymerase (Applied Biosystems) was used. For samples containing $<50 \mathrm{pg} / \mu \mathrm{l}$ DNA, in addition to adding BSA and a double amount of polymerase, the number of cycles was also increased from 28 to 31 , and the extension step within cycles was prolonged to $2 \mathrm{~min}$. The PCR reaction was performed with at most $13 \mu \mathrm{l}$ DNA. Simultaneously with the forensic samples, we amplified the positive control (AmpFlSTR Control DNA 9947A, Applied Biosystems) and negative PCR and extraction controls. For best performance of the PowerPlex 16 System (Promega), the optimal amount of initial genomic DNA is 0.5 to $1 \mathrm{ng}$. For samples containing $>28 \mathrm{pg} / \mu \mathrm{l}$ DNA, PCR was performed according to the manufacturer's instructions [28], but $2.75 \mu$ l of PowerPlex 16 Primer Pair Mix (Promega) was added, and a double amount of AmpliTaq Gold DNA Polymerase (Applied Biosystems) was used. The final extension was prolonged from 30 to $45 \mathrm{~min}$. For samples with a concentration $<28 \mathrm{pg} / \mu \mathrm{l}$, in addition to the measures described above, the number of cycles was increased from 32 to 34 , and the extension step within cycles was prolonged to $90 \mathrm{~s}$. The PCR reaction was performed with at most $18 \mu \mathrm{l}$ DNA. Simultaneously with the forensic samples, we amplified the positive control (Control DNA 9947A, Promega) and negative PCR and extraction controls. For best performance of the AmpFlSTR MiniFiler ${ }^{\mathrm{TM}}$ PCR Amplification Kit (Applied Biosystems), the optimal amount of initial genomic DNA is 0.5 to $0.75 \mathrm{ng}$. For samples containing $>50 \mathrm{pg} / \mu \mathrm{l}$ DNA, PCR was performed according to the manufacturer's instructions [29], but BSA (Sigma; final concentration $40 \mathrm{ng} / \mu \mathrm{l}$ ) was added, and an additional $0.5 \mu$ of AmpliTaq Gold DNA Polymerase (Applied Biosystems) was used. For samples with the concentration $<50 \mathrm{pg} / \mu \mathrm{l}$, in addition to the measures described above, the number of cycles was increased from 30 to 33 , and the extension step within cycles was prolonged to 
$2 \mathrm{~min}$. The PCR reaction was performed with at most $13 \mu \mathrm{l}$ DNA. Simultaneously with the forensic samples, we amplified the positive control (AmpFlSTR Control DNA 007, Applied Biosystems) and negative PCR and extraction controls. For best performance of the PowerPlex ESX 17 System (Promega), the optimal amount of initial genomic DNA is $0.5 \mathrm{ng}$. For samples containing $>29 \mathrm{pg} / \mu \mathrm{l}$ DNA, PCR was performed according to the manufacturer's instructions [30]. For samples with a concentration $<29 \mathrm{pg} / \mu \mathrm{l}$, the number of cycles was increased from 30 to 33, and $6.5 \mu 1$ of PowerPlex ESX 17 5x Master Mix (Promega) was added. The PCR reaction was performed with at most $16 \mu \mathrm{l}$ DNA. Simultaneously with the forensic samples, we amplified the positive control (Control DNA 9947A, Promega) and negative PCR and extraction controls. For best performance of the AmpFlSTR YFilerTM PCR Amplification Kit (Applied Biosystems), the optimal amount of initial genomic DNA is 0.5 to $1 \mathrm{ng}$. For samples containing $>50 \mathrm{pg} / \mu \mathrm{l}$ DNA, PCR was performed according to the manufacturer's instructions [31], but BSA (Sigma; final concentration $40 \mathrm{ng} / \mu \mathrm{l}$ ) was added, and $1.2 \mu \mathrm{l}$ AmpliTaq Gold DNA Polymerase (Applied Biosystems) was used. For samples with a concentration $<50 \mathrm{pg} / \mu \mathrm{l}$, in addition to the measures described above, the number of cycles was increased from 30 to 33 , and the extension step within cycles was prolonged to $2 \mathrm{~min}$. The PCR reaction was performed with at most $13 \mu 1$ DNA. Simultaneously with the forensic samples, we amplified the AmpFlSTR Control DNA 9947A (Applied Biosystems) and AmpFlSTR Control DNA 007 (Applied Biosystems), and the negative PCR and extraction controls.

Fluorescent-labeled products of the amplification kits were separated with an automatic ABI PRISM ${ }^{\mathrm{TM}} 3130$ Genetic Analyzer (Applied Biosystems) using the 3130 Performance Optimized Polymer 4 (Applied Biosystems); the GeneScan-500 LIZ (Applied Biosystems) internal size standard with the kits AmpFlSTR Identifiler, AmpFlSTR MiniFiler, and AmpFlSTR Yfiler PCR Amplification Kit (Applied Biosystems); ILS 600 (Promega) internal size standard with the PowerPlex 16 System (Promega) kit; and CC5 500 (Promega) internal size standard with the PowerPlex ESX 17 System (Promega) kit. Genetic profiles were determined using Data Collection v 3.0 and GeneMapper ID v 3.2 (Applied Biosystems) computer software.

In reference persons, typing of autosomal DNA was performed using the AmpFlSTR Identifiler ${ }^{\mathrm{TM}}$ PCR Amplification Kit (Applied Biosystems); when statistical analysis did not reveal a PP of $99.9 \%$, the PowerPlex 16 System (Promega) amplification kit and PowerPlex ESX 17 System (Promega) were used to obtain the profiles on loci Penta E, Penta D, D10S1248, D1S1656, D22S1045, D2S441, D12S391, and SE33. For the maternal relatives, mtDNA haplotypes were also obtained, and for the paternal relatives, Y-STR haplotypes using the AmpFlSTR Yfiler PCR Amplification Kit (Applied Biosystems). In persons from the elimination database, in addition to autosomal DNA typing using the AmpFlSTR IdentifilerTM PCR Amplification Kit (Applied Biosystems), typing of mtDNA was performed, and for males, also typing of Y-STRs using the AmpFlSTR Yfiler PCR Amplification Kit (Applied Biosystems).

\section{MtDNA sequencing}

The two hypervariable regions HVI and HVII of the mtDNA were amplified by PCR in an ABI PRISM 7000 Sequence Detection System (Applied Biosystems). The primers F15997/R16401 for HVI and F29/R408 for HVII [32] were used. PCR was carried out in a $25-\mu 1$ reaction mixture following Zupanič Pajnič et al. [33], but for the bone samples, $0.8 \mu \mathrm{l}$ of AmpliTaq Gold DNA Polymerase (Applied Biosystems) was used, BSA (Sigma; final concentration $50 \mathrm{ng} / \mu \mathrm{l}$ ) was added, and the number of cycles was increased to 38 . Prior to sequencing, the PCR products were purified using Centricon 100 spin dialysis columns (Millipore Corporation) following the manufacturer's recommendations. Sequencing reactions were performed in a Biometra UNO Thermoblock in both orientations in order to verify the accuracy of base-calling. In cases of length heteroplasmy in the poly-C strand, the polymorphisms behind the $\mathrm{C}$-stretch in the forward sequencing reaction and before the $\mathrm{C}$-stretch in the reverse reaction were confirmed by repeating amplification and sequencing reactions according to the recommendations [15]. Following Bandelt and Parson [34] in cases of heteroplasmic length variants, the dominant variants were reported. The primers used for sequencing the PCR products were the same as for the amplification. Sequencing reactions were carried out using $6 \mu 1$ ABI PRISM BigDye Terminator Cycle Sequencing Ready Reaction Kit, v 1.1 (Applied Biosystems), $8 \mu$ l purified PCR product as a template, $2 \mu 15 \mu \mathrm{M}$ sequencing primer, and $4 \mu \mathrm{l}$ sterile distilled water for each sample. The sequencing conditions and products purification have been described by Zupanič Pajnič et al. [33]. Then, $20 \mu \mathrm{l}$ of Hi-Di' ${ }^{\mathrm{TM}}$ formamide (Applied Biosystems) was added to 15 to $20 \mu 1$ of purified sequencing product, heat denatured, and snap cooled on ice. Automated DNA sequencing was carried out on an ABI PRISM $^{\text {TM }} 3130$ Genetic Analyser (Applied Biosystems) using the 3130 Performance Optimized Polymer POP 4 (Applied Biosystems) and Data Collection v 3.0 Software (Applied Biosystems). The denatured samples were electrokinetically injected for $10 \mathrm{~s}$ at $1.2 \mathrm{kV}$ into a $36-\mathrm{cm}$ capillary array. Electrophoresis was run at $15 \mathrm{kV}$ and $60^{\circ} \mathrm{C}$ with the UltraSeq36 POP4 sequencing module. The analysis of mtDNA sequencing data was performed using $A B$ DNA Sequencing Analysis Software v 5.2 (Applied Biosystems). The sequences were aligned and compared with the Anderson sequence [35] from 16030 to 16381 for the HVI region and from 55 to 388 for the HVII region using BioEdit software. 
Statistical analysis

Genetic profiles obtained from the bones and reference samples were compared, and estimation of potential familiar relationships was performed. The calculation of LRs and posterior probabilities (PP) was performed with DNA VIEW software v.28.48 and 29.03 [36], mainly using allele frequencies of the Slovenian population $[37,38]$ and prior probability 1/89 [39]. LRs for chromosome Y-haplotypes and mtDNA haplotypes were calculated based on haplotype frequencies in various databases [40]. The counting method was used to estimate the haplotype frequencies, and the Balding and Nichols [41] correction for errors in sampling was considered $[17,42]$. The reference database YHRD [43] and EMPOP [44] were used to determine the Y-chromosome and mtDNA haplotype frequencies. In the YHRD database, we used European metapopulation with 5,342 haplotypes, and in the EMPOP database, we used west Eurasian populations with 4,476 haplotypes. Whenever an agreement of autosomal genetic profiles and mtDNA haplotypes was noted between the bone and a relative, the product rule was used to estimate a combined LR [45]. The same was applied when an agreement was noted between autosomal genetic profiles and Y-STR haplotypes [42]. Following recommendations $[5,39,46]$, the prior probability was set based on the number of victims reported (the recorded list of victims in the Konfin I mass grave), and a recommended PP (for kinship) of $99.9 \%$ was used (an LR of at least $8.8 \times 10^{4}$ needed to be reached) with the goal of high confidence of correct identification of victims in the mass grave.

The genetic profiles obtained for the bones were compared to the profiles of persons included in the elimination database to monitor possible contamination of bone samples with modern DNA.

\section{Results and discussion}

For DNA isolation from bones, Nagy et al. [47] used a BioRobot M48 (Qiagen). Our laboratory used a Biorobot EZ1 (Qiagen) for the same purpose. Montpetit et al. [48], Valgren et al. [49], and Kishore et al. [50] obtained DNA from various casework samples with a Biorobot EZ1 (Qiagen), for which they found a high purification efficacy. Prior to extraction, we decalcified the bone. After $72 \mathrm{~h}$ of decalcification, precipitate with incompletely decalcified bone powder was usually obtained.

Quantification of nuclear DNA resulted in determination of over $8 \mathrm{pg} \mathrm{DNA} / \mu \mathrm{l}$ of isolate in all bones, with the exception of two femurs (Table 1). We detected 8 to $16 \mathrm{pg} \mathrm{DNA} / \mu 1$ of isolate in six bones only (100 to $200 \mathrm{pg}$ DNA was amplified in PCR), whereas in 76 bones (90\%), we detected more than $16 \mathrm{pg} \mathrm{DNA} / \mu \mathrm{l}$ of isolate, which means that the initial amount of DNA in the PCR exceeded 200 pg DNA, the limit for low copy number PCR [51, 52]. In six bones in which the initial amount of DNA in the PCR did not exceeded $200 \mathrm{pg}$, the autosomal and Y-STR loci were amplified in parallel, and only duplicated alleles were reported for comparison with the reference samples. In 28 of the 76 bones in which the initial amount of DNA in the PCR exceeded $200 \mathrm{pg}$, discrepancies were noted between the AmpFlSTR Identifiler ${ }^{\mathrm{TM}}$ PCR Amplification Kit (Applied Biosystems) and PowerPlex 16 System (Promega) for the shared loci. The heterozygote call for one locus in one amplification kit and an apparent homozygous call in the other amplification kit were noted 53 times, and heterozygote calls were interpreted.

The typing of autosomal and Y-STR loci was successful in 82 of the 84 bones, which represents a $98 \%$ success rate. Complete autosomal genetic profiles (17 STR loci and amelogenin) were obtained from 59 bones, partial profiles with one or two STR loci missing were obtained from 17 bones (primarily longer loci Penta E, Penta D, or D2S1338 were missing), and in the remaining six bones, 11 to 15 loci were amplified (Table 1). Complete Y-STR profiles (17 STR loci) were obtained from 41 bones, partial profiles with one or two missing Y-STR loci from 15 bones, in 16 bones, ten to 14 loci were amplified, and in the remaining ten bones, six to nine Y-STR loci were amplified (Table 1). The typing of the mtDNA HVI region was successful in 80 of the 84 bones, which represents a $95 \%$ success rate, and the typing of mtDNA HVII region was successful in 82 of the 84 bones, which represents a $98 \%$ success rate (Table 1). Palo et al. [4] used mtDNA analysis to identify skeletal remains of Finnish soldiers killed in the Second World War in the former Soviet Union and found the success rate of typing for long bones to be $96 \%$ in the HVI region and $91 \%$ in the HVII region. Of the 80 bones in the HVI region, eight (10\%) had length heteroplasmy, and of the 82 bones in the HVII region, 23 (28\%) had length heteroplasmy.

Of the 88 victims in the Konfin I mass grave, we managed to trace living relatives of 36 victims; they served for comparison with genetic profiles of the bones from the mass grave. Of the 84 bones found, we matched 28 bones with relatives and identified 28 victims of the massacre. Fourteen victims were identified by comparison to living sisters: we compared autosomal STRs and mtDNA haplotypes. In autosomal STRs, the values for LR ranged between $1.9 \times 10^{2}$ and $4.1 \times 10^{9}$, and in mtDNA haplotypes between $7.5 \times 10^{1}$ and $2.2 \times 10^{3}$, whereas the values for the combined LR ranged between $4.2 \times 10^{5}$ and $9.2 \times 10^{12}$ (PP ranged between $99.97 \%$ and $>99.999999 \%$ ). In addition, a maternal-line cousin served for comparison of autosomal STRs and mtDNA haplotypes, which helped identify one victim. The calculated values for combined LR and PP were $1.3 \times 10^{5}$ and $99.92 \%$, respectively. In addition, 
Table 1 Maximal nuclear DNA quantity (QuantifilerTM Human DNA Quantification Kit, Applied Biosystems), expressed in pg DNA/ $\mu 1$ of isolate; efficiency of autosomal DNA typing (AmpFlSTR Identifiler ${ }^{\mathrm{TM}}$ PCR Amplification Kit (Applied Biosystems) and PowerPlex 16 System,
Promega), expressed as the number of successfully typed autosomal short tandem repeats (STRs); efficiency of Y-STR typing, expressed as the number of successfully typed Y-STRs; and efficiency of mtDNA typing (HVI and HVII) of the bones found in the Konfin I grave

\begin{tabular}{|c|c|c|c|c|}
\hline Bone sample & Maximum quantity $(\mathrm{pg} / \mu \mathrm{l})$ & Autosomal STR loci & Y-STR loci & mtDNA \\
\hline Femur A ant & 221 & $18 / 18$ & $17 / 17$ & HVI, HVII \\
\hline Femur B ant & 32 & $18 / 18$ & $7 / 17$ & HVI, HVII \\
\hline Femur $\mathrm{C}$ ant & 60 & $17 / 18$ & $17 / 17$ & HVI, HVII \\
\hline Femur D ant & 37 & $18 / 18$ & $17 / 17$ & HVI, HVII \\
\hline Femur E ant & 70 & $18 / 18$ & $17 / 17$ & HVI, HVII \\
\hline Femur $\mathrm{F}$ ant & 50 & $18 / 18$ & $14 / 17$ & HVI, HVII \\
\hline Femur $\mathrm{G}$ ant & 40 & $17 / 18$ & $12 / 17$ & HVI, HVII \\
\hline Femur $\mathrm{H}$ ant & 106 & $18 / 18$ & $17 / 17$ & HVI, HVII \\
\hline Femur I ant & 26 & $17 / 18$ & $17 / 17$ & HVI, HVII \\
\hline R Femur 43 pat & 237 & $18 / 18$ & $17 / 17$ & HVI, HVII \\
\hline R Femur 45 pat & 46 & $17 / 18$ & $14 / 17$ & HVI, HVII \\
\hline R Femur 49 pat & 116 & $18 / 18$ & $17 / 17$ & HVI, HVII \\
\hline R Femur 51 pat & 56 & $18 / 18$ & $17 / 17$ & HVI, HVII \\
\hline R Femur 1 & 62 & $18 / 18$ & $16 / 17$ & HVI, HVII \\
\hline R Femur 2 & 10 & $13 / 18$ & $12 / 17$ & \\
\hline R Femur 3 & 43 & $18 / 18$ & $16 / 17$ & HVI, HVII \\
\hline R Femur 4 & 21 & $17 / 18$ & $16 / 17$ & HVI, HVII \\
\hline R Femur 5 & 18 & $16 / 18$ & $14 / 17$ & HVI, HVII \\
\hline R Femur 6 & 10 & $14 / 18$ & $7 / 17$ & HVII \\
\hline R Femur 7 & 24 & $18 / 18$ & $17 / 17$ & HVI, HVII \\
\hline R Femur 8 & 69 & $18 / 18$ & $16 / 17$ & HVI, HVII \\
\hline R Femur 9 & 17 & $18 / 18$ & $16 / 17$ & HVI, HVII \\
\hline R Femur 10 & 46 & $18 / 18$ & $16 / 17$ & HVI, HVII \\
\hline R Femur 11 & 114 & $18 / 18$ & $17 / 17$ & HVI, HVII \\
\hline R Femur 12 & 120 & $18 / 18$ & $17 / 17$ & HVI, HVII \\
\hline R Femur 13 & 35 & $18 / 18$ & $17 / 17$ & HVI, HVII \\
\hline R Femur 14 & 60 & $16 / 18$ & $13 / 17$ & HVI, HVII \\
\hline R Femur 15 & 100 & $18 / 18$ & $17 / 17$ & HVI, HVII \\
\hline R Femur 16 & 51 & $18 / 18$ & $8 / 17$ & HVI, HVII \\
\hline R Femur 17 & 110 & $18 / 18$ & $17 / 17$ & HVI, HVII \\
\hline R Femur 18 & 1,000 & $18 / 18$ & $17 / 17$ & HVI, HVII \\
\hline R Femur 19 & 270 & $18 / 18$ & $17 / 17$ & HVI, HVII \\
\hline R Femur 20 & 15 & $11 / 18$ & $14 / 17$ & HVI, HVII \\
\hline R Femur 21 & 142 & $18 / 18$ & $17 / 17$ & HVI, HVII \\
\hline R Femur 22 & 111 & $18 / 18$ & $17 / 17$ & HVI, HVII \\
\hline R Femur 23 & 130 & $18 / 18$ & $17 / 17$ & HVI, HVII \\
\hline R Femur 24 & 75 & $18 / 18$ & $17 / 17$ & HVI, HVII \\
\hline R Femur 25 & 36 & $18 / 18$ & $17 / 17$ & HVI, HVII \\
\hline R Femur 26 & 39 & $16 / 18$ & $15 / 17$ & HVI, HVII \\
\hline R Femur 27 & 150 & $18 / 18$ & $16 / 17$ & HVI, HVII \\
\hline R Femur 28 & 41 & $18 / 18$ & $17 / 17$ & HVI, HVII \\
\hline R Femur 29 & 48 & $15 / 18$ & $6 / 17$ & HVI, HVII \\
\hline R Femur 30 & 64 & $18 / 18$ & $17 / 17$ & HVI, HVII \\
\hline R Femur 31 & 17 & $16 / 18$ & $13 / 17$ & HVI, HVII \\
\hline R Femur 32 & 42 & $18 / 18$ & $17 / 17$ & HVI, HVII \\
\hline R Femur 33 & 100 & $18 / 18$ & $17 / 17$ & HVI, HVII \\
\hline
\end{tabular}


Table 1 (continued)

\begin{tabular}{|c|c|c|c|c|}
\hline Bone sample & Maximum quantity $(\mathrm{pg} / \mu \mathrm{l})$ & Autosomal STR loci & Y-STR loci & mtDNA \\
\hline R Femur 34 & 62 & $18 / 18$ & $16 / 17$ & HVI, HVII \\
\hline R Femur 35 & 64 & $18 / 18$ & $10 / 17$ & HVI, HVII \\
\hline R Femur 36 & 77 & $16 / 18$ & $16 / 17$ & HVI, HVII \\
\hline R Femur 37 & 280 & $18 / 18$ & $17 / 17$ & HVI, HVII \\
\hline R Femur 38 & 130 & $18 / 18$ & $17 / 17$ & HVI, HVII \\
\hline R Femur 39 & 150 & $18 / 18$ & $17 / 17$ & HVI, HVII \\
\hline R Femur 40 & 30 & $17 / 18$ & $17 / 17$ & \\
\hline R Femur 41 & 50 & $18 / 18$ & $17 / 17$ & HVI, HVII \\
\hline R Femur 42 & 43 & $17 / 18$ & $12 / 17$ & HVI, HVII \\
\hline R Femur 43 & 8 & $14 / 18$ & $14 / 17$ & HVI, HVII \\
\hline R Femur 44 & 26 & $17 / 18$ & $17 / 17$ & HVI, HVII \\
\hline R Femur 45 & 57 & $18 / 18$ & $17 / 17$ & HVI, HVII \\
\hline R Femur 46 & 47 & $24 / 24$ & $7 / 17$ & HVI, HVII \\
\hline R Femur 47 & 77 & $18 / 18$ & $17 / 17$ & HVII \\
\hline R Femur 48 & 100 & $18 / 18$ & $17 / 17$ & HVI, HVII \\
\hline R Femur 49 & 101 & $18 / 18$ & $10 / 17$ & HVI, HVII \\
\hline R Femur 50 & 90 & $18 / 18$ & $9 / 17$ & HVI, HVII \\
\hline R Femur 51 & 47 & $18 / 18$ & $7 / 17$ & HVI, HVII \\
\hline R Femur 52 & 18 & $18 / 18$ & $17 / 17$ & HVI, HVII \\
\hline R Femur 53 & 91 & $18 / 18$ & $8 / 17$ & HVI, HVII \\
\hline R Femur 54 & 14 & $14 / 18$ & $16 / 17$ & HVI, HVII \\
\hline R Femur 55 & 120 & $18 / 18$ & $10 / 17$ & HVI, HVII \\
\hline R Femur 56 & 109 & $18 / 18$ & $17 / 17$ & HVI, HVII \\
\hline R Femur 57 & 73 & $18 / 18$ & $10 / 17$ & HVI, HVII \\
\hline R Femur 58 & 48 & $17 / 18$ & $17 / 17$ & HVI, HVII \\
\hline R Femur 59 & 47 & $18 / 18$ & $9 / 17$ & HVI, HVII \\
\hline R Femur 60 & 24 & $18 / 18$ & $16 / 17$ & HVI, HVII \\
\hline R Femur 61 & 250 & $18 / 18$ & $17 / 17$ & HVI, HVII \\
\hline R Femur 62 & 33 & $18 / 18$ & $14 / 17$ & HVI, HVII \\
\hline R Femur 63 & 17 & $17 / 18$ & $16 / 17$ & HVI, HVII \\
\hline R Femur 64 & 18 & $18 / 18$ & $15 / 17$ & HVI, HVII \\
\hline R Femur 65 & 4 & $0 / 18$ & $0 / 17$ & HVI, HVII \\
\hline R Femur 66 & 36 & $18 / 18$ & $17 / 17$ & HVI, HVII \\
\hline R Femur 67 & 34 & $18 / 18$ & $17 / 17$ & HVI, HVII \\
\hline R Femur 68 & 5 & $0 / 18$ & $0 / 17$ & HVI, HVII \\
\hline R Femur 69 & 93 & $18 / 18$ & $7 / 17$ & HVI, HVII \\
\hline R Femur 70 & 15 & $22 / 24$ & $11 / 17$ & HVI, HVII \\
\hline R Femur 71 & 51 & $17 / 18$ & $16 / 17$ & HVI, HVII \\
\hline
\end{tabular}

a maternal-line nephew served for comparison of autosomal STRs and mtDNA haplotypes that helped match one victim; after analyzing additional six STR loci, the statistical analysis showed high confidence of correct identification: the combined LR was $8.9 \times 10^{4}$ and PP, $99.9 \%$. Six victims were identified by comparison to living brothers; we compared autosomal STRs, mtDNA haplotypes, and Y-STR haplotypes. In autosomal STRs, the values for LR ranged between $2.3 \times 10^{2}$ and $3 \times 10^{5}$, and in
mtDNA haplotypes, between $5.6 \times 10^{2}$ and $2.2 \times 10^{3}$; in YSTR haplotypes, the values for LR ranged between $5.9 \times$ $10^{2}$ and $2.7 \times 10^{3}$, the values for combined LR (autosomal DNA and mtDNA) ranged between $1.3 \times 10^{5}$ and $2.4 \times 10^{8}$ (PP ranged between $99.92 \%$ and $99.99996 \%$ ), and the values for combined LR (autosomal DNA and Y-STRs) ranged between $6.2 \times 10^{5}$ and $7.3 \times 10^{8}$ (PP ranged between $99.98 \%$ and $99.99998 \%$ ). One victim was identified by comparison to a living son; we compared autosomal STRs 
and Y-STR haplotypes. In autosomal STRs, the value for LR was $9.2 \times 10^{4}$, in the Y-STR haplotype, the value for LR was $2.7 \times 10^{3}$, and the value for combined LR (autosomal DNA and Y-STRs) was $2.5 \times 10^{8}$ (PP was $99.99996 \%$ ). One victim was identified by comparison to a living daughter and wife; we were able to compare autosomal STRs only. The value for LR was $3.7 \times 10^{6}$ and for PP, $99.997 \%$. The last four victims were matched to living daughters; in these cases, we were able to compare autosomal STRs only, because no appropriate reference persons were available for the comparison of mtDNA haplotypes and Y-STR haplotypes. After the analysis of additional six STR loci for one victim, the statistical analysis showed high confidence of correct identification for all four victims with daughters as reference persons. The LR values ranged between $2.5 \times$ $10^{5}$ and $5.9 \times 10^{5}$, and PP ranged between $99.96 \%$ and 99.98\% (Tables 2 and 3).

We managed to obtain nuclear DNA from bones over 60 years old for successful STR typing. Of the total 36 possible identifications (of the 88 victims, reference samples were obtained for 36 massacre victims only), we matched 28 victims to living relatives with high confidence of correct identification (PP ranged from $99.9 \%$ to more than $99.999999 \%)$. Similar to the experience of Irwin et al. [6], our experience shows that a combination of a higher number of genetic markers provides extremely high LRs that support the hypothesis that individuals' bones are related to the family references, rather than unrelated individuals. If we had analyzed only autosomal STR loci, we would have been able to identify only 12 victims with a high confidence of correct identification. Therefore, we deem it necessary to also include Y-STRs and mtDNA analyses and close as well as distant relatives of the maternal and paternal lines in the identification of Second World War victims. Of the 84 bones, 56 could not be matched to living relatives and, therefore, could not be identified. Their genetic profiles are waiting for the possibility of identification after new reference samples are obtained.

In spite of the complete list of 88 victims taken from the Central Prison on the night of 24 June 1945, we were not
Table 2 Likelihood ratio (LR) and posterior probability (assuming $1 / 89$ as the prior probability) for autosomal DNA (n-short tandem repeat (STR)), LR for mtDNA, and LR for Y-STRs, for the identified victims found in the Konfin I grave

In reference sample, kinship with the victim is indicated

${ }^{\mathrm{a}}$ Femur $\mathrm{D}$ ant and $\mathrm{R}$ femur 11 are brothers

\begin{tabular}{|c|c|c|c|c|c|}
\hline Bone & Reference & $\mathrm{LR}_{(\mathrm{n}-\mathrm{STR})}$ & $\mathrm{PP}_{(\mathrm{n}-\mathrm{STR})}$ & $\mathrm{LR}_{(\mathrm{mtDNA})}$ & $\mathrm{LR}_{(\mathrm{Y}-\mathrm{STR})}$ \\
\hline Femur D ant $\mathrm{a}^{\mathrm{a}}$ & Sister & $4.1 \times 10^{9}$ & $99.999998 \%$ & $2.2 \times 10^{3}$ & \\
\hline R Femur $11^{\mathrm{a}}$ & Sister & $4.8 \times 10^{6}$ & $99.998 \%$ & $2.2 \times 10^{3}$ & \\
\hline Femur E ant & Sister & $1.8 \times 10^{4}$ & $99.5 \%$ & $2.2 \times 10^{3}$ & \\
\hline R Femur 43 pat & Sister & $6.8 \times 10^{2}$ & $87.3 \%$ & $1.5 \times 10^{3}$ & \\
\hline R Femur 66 & Sister & $8.0 \times 10^{3}$ & $98.8 \%$ & $2.2 \times 10^{3}$ & \\
\hline R Femur 9 & Sister & $1.4 \times 10^{3}$ & $93.4 \%$ & $2.2 \times 10^{3}$ & \\
\hline Femur B ant & Sister & $3.9 \times 10^{4}$ & $99.7 \%$ & $1.7 \times 10^{2}$ & \\
\hline R Femur 20 & Sister & $1.9 \times 10^{2}$ & $65.0 \%$ & $2.2 \times 10^{3}$ & \\
\hline R Femur 26 & Sister & $2.6 \times 10^{3}$ & $96.3 \%$ & $2.2 \times 10^{3}$ & \\
\hline R Femur 30 & Sister & $6.7 \times 10^{3}$ & $98.7 \%$ & $7.5 \times 10^{1}$ & \\
\hline R Femur 42 & Sister & $3.7 \times 10^{3}$ & $97.4 \%$ & $2.2 \times 10^{3}$ & \\
\hline R Femur 44 & Sister & $1.6 \times 10^{5}$ & $99.94 \%$ & $2.2 \times 10^{3}$ & \\
\hline R Femur 52 & Sister & $5.7 \times 10^{5}$ & $99.98 \%$ & $1.5 \times 10^{2}$ & \\
\hline R Femur 61 & Sister & $1.9 \times 10^{4}$ & $99.5 \%$ & $2.2 \times 10^{3}$ & \\
\hline R Femur 34 & Cousin & $5.8 \times 10^{1}$ & $37.0 \%$ & $2.2 \times 10^{3}$ & \\
\hline R Femur 46 & Nephew & $4.0 \times 10^{1}$ & $28.8 \%$ & $2.2 \times 10^{3}$ & \\
\hline R Femur 49 pat & Brother & $2.3 \times 10^{4}$ & $99.6 \%$ & $2.2 \times 10^{3}$ & $2.7 \times 10^{3}$ \\
\hline Femur $\mathrm{G}$ ant & Brother & $2.6 \times 10^{3}$ & $96.3 \%$ & $2.2 \times 10^{3}$ & $5.9 \times 10^{2}$ \\
\hline R Femur 14 & Brother & $2.3 \times 10^{2}$ & $70.0 \%$ & $5.6 \times 10^{2}$ & $2.7 \times 10^{3}$ \\
\hline R Femur 18 & Brother & $2.7 \times 10^{5}$ & $99.96 \%$ & $9.0 \times 10^{2}$ & $2.7 \times 10^{3}$ \\
\hline R Femur 19 & Brother & $3.0 \times 10^{5}$ & $99.97 \%$ & $7.5 \times 10^{2}$ & $7.6 \times 10^{2}$ \\
\hline R Femur 43 & Brother & $3.8 \times 10^{3}$ & $97.5 \%$ & $1.5 \times 10^{3}$ & $2.7 \times 10^{3}$ \\
\hline R Femur 40 & Son & $9.2 \times 10^{4}$ & $99.9 \%$ & & $2.7 \times 10^{3}$ \\
\hline R Femur 23 & Daughter and wife & $3.7 \times 10^{6}$ & $99.997 \%$ & & \\
\hline R Femur 41 & Daughter & $5.9 \times 10^{5}$ & $99.98 \%$ & & \\
\hline R Femur 48 & Daughter & $3.8 \times 10^{5}$ & $99.97 \%$ & & \\
\hline R Femur 53 & Daughter & $2.5 \times 10^{5}$ & $99.96 \%$ & & \\
\hline R Femur 70 & Daughter & $4.6 \times 10^{5}$ & $99.98 \%$ & & \\
\hline
\end{tabular}


Table 3 Combined likelihood ratio and posterior probability (assuming 1/89 as the prior probability) for identified victims found in the Konfin I mass grave

\begin{tabular}{|c|c|c|c|c|c|}
\hline Bone & Reference & $\mathrm{LR}_{(\mathrm{n}-\mathrm{STR} \times \mathrm{mtDNA})}$ & $\left.\mathrm{PP}_{(\mathrm{n}-\mathrm{STR}} \times \mathrm{mtDNA}\right)$ & $\mathrm{LR}_{(\mathrm{n}-\mathrm{STR} \times \mathrm{Y} \text {-STR) }}$ & $\mathrm{PP}_{(\mathrm{n}-\mathrm{STR} \times \mathrm{Y} \text {-STR) }}$ \\
\hline Femur D ant ${ }^{\mathrm{a}}$ & Sister & $9.2 \times 10^{12}$ & $>99.999999 \%$ & & \\
\hline R Femur $11^{\mathrm{a}}$ & Sister & $1.1 \times 10^{10}$ & $>99.999999 \%$ & & \\
\hline Femur E ant & Sister & $4.0 \times 10^{7}$ & $99.9998 \%$ & & \\
\hline R Femur 43 pat & Sister & $1.0 \times 10^{6}$ & $99.99 \%$ & & \\
\hline R Femur 66 & Sister & $1.8 \times 10^{7}$ & $99.9995 \%$ & & \\
\hline R Femur 9 & Sister & $3.2 \times 10^{6}$ & $99.997 \%$ & & \\
\hline Femur B ant & Sister & $6.7 \times 10^{6}$ & $99.999 \%$ & & \\
\hline R Femur 20 & Sister & $4.2 \times 10^{5}$ & $99.97 \%$ & & \\
\hline R Femur 26 & Sister & $5.9 \times 10^{6}$ & $99.998 \%$ & & \\
\hline R Femur 30 & Sister & $5.0 \times 10^{5}$ & $99.98 \%$ & & \\
\hline R Femur 42 & Sister & $8.4 \times 10^{6}$ & $99.999 \%$ & & \\
\hline R Femur 44 & Sister & $3.7 \times 10^{8}$ & $99.99997 \%$ & & \\
\hline R Femur 52 & Sister & $8.5 \times 10^{7}$ & $99.9999 \%$ & & \\
\hline R Femur 61 & Sister & $4.2 \times 10^{7}$ & $99.9998 \%$ & & \\
\hline R Femur 34 & Cousin & $1.3 \times 10^{5}$ & $99.92 \%$ & & \\
\hline R Femur 46 & Nephew & $8.9 \times 10^{4}$ & $99.9 \%$ & & \\
\hline R Femur 49 pat & Brother & $5.1 \times 10^{7}$ & $99.9998 \%$ & $6.2 \times 10^{7}$ & $99.9998 \%$ \\
\hline Femur $\mathrm{G}$ ant & Brother & $5.8 \times 10^{6}$ & $99.998 \%$ & $1.5 \times 10^{6}$ & $99.994 \%$ \\
\hline R Femur 14 & Brother & $1.3 \times 10^{5}$ & $99.92 \%$ & $6.2 \times 10^{5}$ & $99.98 \%$ \\
\hline R Femur 18 & Brother & $2.4 \times 10^{8}$ & $99.99996 \%$ & $7.3 \times 10^{8}$ & $99.99998 \%$ \\
\hline R Femur 19 & Brother & $2.2 \times 10^{8}$ & $99.99996 \%$ & $2.3 \times 10^{8}$ & $99.99996 \%$ \\
\hline R Femur 43 & Brother & $5.7 \times 10^{6}$ & $99.998 \%$ & $1.0 \times 10^{7}$ & $99.999 \%$ \\
\hline R Femur 40 & Son & & & $2.5 \times 10^{8}$ & $99.99996 \%$ \\
\hline
\end{tabular}

In the reference sample, kinship with the victim is indicated

${ }^{\mathrm{a}}$ Femur $\mathrm{D}$ ant and $\mathrm{R}$ femur 11 are brothers

able to make identifications for all 36 victims for which family reference samples were received. We were able to make identifications for 28 of them. The other eight victims for whom references were available failed to match. There is another mass grave Konfin II only $20 \mathrm{~m}$ away from the mass grave Konfin I. It is known that the massacre in Konfin II happened only 2 days after the massacre in Konfin I. On the list of victims taken from the Central Prison on the night of 26 June 1945, there are 48 persons. The skeletal remains were not excavated from the mass grave Konfin II yet. We assume that among the skeletal remains from mass grave Konfin II, the victims from the list of mass grave Konfin I would be found.

In the process of identifying victims in the Konfin I mass grave, we minimized the possibility of contamination during genetic investigations. The authenticity of genetic profiles of bones was confirmed by clean isolation and amplification-negative controls for nuclear DNA, identical genetic profiles obtained using the AmpFlSTR Identifiler ${ }^{\mathrm{TM}}$ PCR Amplification Kit (Applied Biosystems) and PowerPlex 16 System (Promega), and mismatch of genetic profiles of bones with persons from the elimination database. Because of the high detection sensitivity of mtDNA analysis, low levels of exogenous DNA contamination were observed in extraction-negative controls and PCR-negative controls. The level of contamination was lower in the PCR-negative controls than in the extraction-negative controls. The haplotype of two extraction-negative controls matched the analyst, but no haplotype of the bone samples yielded the same sequence.

Identifying the victims in the Konfin I mass grave establishes a basis for further molecular genetic investigations of postwar mass graves in Slovenia when the possibility arises. We should stress the fact that mass graves with lists of victims are rare. The mass grave Konfin I represents such a rarity as it was possible to make a list of victims on a basis of archived documents. The methods of DNA extraction and amplification described here have proved to be highly efficient because we obtained 0.8 to $100 \mathrm{ng} \mathrm{DNA} / \mathrm{g}$ of bones and complete genetic profiles of autosomal DNA, Y-STR haplotypes, and of mtDNA haplotypes. It should also be noted that the environment where these bones were preserved may favor DNA preservation. On the other hand, we obtained similar results 
(successful typing of nuclear DNA and mtDNA) from two mass graves not located in karst caves: in identifying three victims in the grave at Mount Storžič $[8,9]$ and DNA typing of 25 victims in the Bodovlje Gorge (Bodoveljska grapa) mass grave (data not published yet).

DNA extraction proved effective from relatively small $0.5-\mathrm{g}$ bone samples. The identity of the genetic profiles of bone specimens was verified by amplification of STRs with two different amplification kits. For degraded samples, we additionally used the amplification kit for mini-STRs. In two cases, in which statistical analysis were too low after amplification of STRs with the kits AmpFlSTR Identifiler (Applied Biosystems) and PowerPlex 16 System (Promega), the PowerPlex ESX 17 System (Promega) amplification kit was used to reach the LR of $8.8 \times 10^{4}$. When the genetic profiles of bones matched living relatives, the recommended PP of 99.9\% was higher in all identifications, indicating that a sufficient number of genetic markers were investigated in identifying skeletal remains.

Acknowledgement The authors gratefully acknowledge Katja Vodopivec Mohorčič's contribution to cleaning and pulverizing the Second World War bones and extracting the DNA from them.

Open Access This article is distributed under the terms of the Creative Commons Attribution Noncommercial License which permits any noncommercial use, distribution, and reproduction in any medium, provided the original author(s) and source are credited.

\section{References}

1. Anderung C, Persson P, Bouwman A, Elburg R, Gotherstrom A (2008) Fishing for ancient DNA. Forensic Sci Int: Genetics 2:104-107

2. Anslinger K, Weichhold G, Keil W, Bayer B, Eisenmenger W (2001) Identification of the skeletal remains of Martin Bormann by mtDNA analysis. Int J Legal Med 114:194-196

3. Stone AC, Starrs JE, Stoneking M (2001) Mitochondrial DNA analysis of the presumptive remains of Jesse James. J Forensic Sci 46:173-176

4. Palo JU, Hedman M, Soderholm N, Sajantila A (2007) Repatriation and identification of finnish World War II soldiers. Croat Med J 48:528-535

5. Biesecker LG, Bailey-Wilson JE, Ballantyne J, Baum H, Bieber FR, Brenner C, Budowle B, Butler JM, Carmody G, Conneally PM, Duceman B, Eisenberg A, Forman L, Kidd KK, Leclair B, Niezgoda S, Parsons TJ, Pugh E, Shaler R, Sherry ST, Sozer A, Walsh A (2005) DNA identification after the 9/11 world trade center attack. Science 310:1122-1123

6. Irwin JA, Edson SM, Loreille O, Just RS, Barritt SM, Lee DA, Holland TD, Parsons TJ, Leney MD (2007) DNA identification of "Earthquake McGoon" 50 years postmortem. J Forensic Sci 52:1115-1118

7. Marjanović D, Durmić-Pašić A, Bakal N, Haverić S, Kalamujić B, Kovačević L, Ramić J, Pojskić N, Škaro V, Projić P, Bajrović K, Hadžiselimović R, Drobnič K, Huffine E, Davoren J, Primorac D (2007) DNA identification of skeletal remains from World War II mass graves uncovered in Slovenia. Croat Med J 48:513-519
8. Zupanič Pajnič I (2008) Molekularnogenetska identifikacija domobranskih žrtev (Molecular genetic identification of Slovenian home guard victims). Zdrav Vestn 77:745-750

9. Zupanič Pajnič I (2008) Molekularno-genetska identifikacija žrtev medvojnih pobojev pod Storžičem (Molecular genetic identification of victims of wartime killings below Mount Storžič). In: Dežman J (ed) Poročilo Komisije Vlade Republike Slovenije za reševanje vprašanj prikritih grobišč 2005-2008. Družina, Ljubljana, pp 219-250

10. Marjanović D, Durmić-Pašić A, Kovačević L, Avdić J, Džehverović M, Ramić J, Kalamujić B, Lukić Bilela L, Škaro V, Projić P, Bajrović K, Drobnič K, Davoren J, Primorac D (2009) Identification of skeletal remains of communist armed forces victims during and after World War II: combined Y-chromosome short tandem repeat (STR) and MiniSTR approach. Croat Med J 50:296-303

11. Definis Gojanović M, Sutlović D (2007) Skeletal remains from World War II mass grave: from discovery to identification. Croat Med J 48:520-527

12. Ferenc M (2008) Topografija evidentiranih grobišč (Topography of documented mass graves). In: Dežman J (ed) Poročilo Komisije Vlade Republike Slovenije za reševanje vprašanj prikritih grobišč 2005-2008. Družina, Ljubljana, pp 7-27

13. Jamnik P (2008) Ugotavljanje identitete žrtev iz brezna pri Konfinu I v arhivskih virih (Identifying victims in the Konfin I mass grave using the documents from the archives). In: Dežman J (ed) Poročilo Komisije Vlade Republike Slovenije za reševanje vprašanj prikritih grobišč 2005-2008. Družina, Ljubljana, pp 83-93

14. Alonso A, Andelinović Š, Martin P (2001) DNA typing from skeletal remains: evaluation of multiplex and megaplex STR systems on DNA isolated from bone and teeth samples. Croat Med J 42:260-266

15. Tully G, Bär W, Brinkmann B, Carracedo A, Gill P, Morling N (2001) Considerations by the European DNA profiling (EDNAP) group on the working practices nomenclature and interpretation of mitochondrial DNA profiles. Forensic Sci Int 124:83-91

16. Bär W, Brinkmann B, Budowle B, Carracedo A, Gill P, Holland M (2000) DNA commission of the international society for forensic genetics: guidelines for mitochondrial DNA typing. Int J Legal Med 113:193-196

17. Carracedo A, Bär W, Lincoln P, Mary W (2000) DNA commission of the international society for forensic genetics: guidelines for mitochondrial DNA typing. Forensic Sci Int 110:79-85

18. Kemp BM, Smith DG (2005) Use of bleach to eliminate contaminating DNA from the surface of bones and teeth. Forensic Sci Int 154:53-61

19. Wilson MR, DiZinno JA, Polanskey D, Replogle J, Budowle B (1995) Validation of mitochondrial DNA sequencing for forensic casework analysis. Int J Legal Med 108:68-74

20. Kalmar T, Bachrati CZ, Marcsik A, Rasko I (2000) A simple and efficient method for PCR amplifiable DNA extraction from ancient bones. Nucleic Acids Res 28:e67

21. Davoren J, Vanek D, Konjhodzić R, Crews J, Huffine E, Parsons TJ (2007) Highly effective DNA extraction method for nuclear short tandem repeat testing of skeletal remains from mass graves. Croat Med J 48:478-485

22. Tamariz J, Voynarovska K, Prinz M, Caragine T (2006) The application of ultraviolet irradiation to exogenous sources of DNA in plasticware and water for the amplification of low copy number DNA. J Forensic Sci 51:790-794

23. Shaw K, Sesardić I, Bristol N, Ames C, Dagnall K, Ellis C, Whittaker F, Daniel B (2008) Comparison of the effects of sterilisation techniques on subsequent DNA profiling. Int J Legal Med 122:29-33

24. Vanek D, Saskova L, Koch H (2009) Kinship and Y-chromosome analysis of 7th century human remains: novel DNA extraction and typing procedure for ancient material. Croat Med J 50:286-295 
25. Companies Q (2004) EZ1 DNA handbook. Qiagen Companies, Vienna

26. Biosystems A (2003) Quantifiler ${ }^{\mathrm{TM}}$ human DNA quantification kit user guide. Applied Biosystems, Foster City

27. Biosystems A (2001) AmpFlSTR identifiler ${ }^{\text {TM }}$ PCR amplification kit user guide. Applied Biosystems, Foster City

28. Corporation P (2007) PowerPlex 16 system technical manual. Promega Corporation, Madison

29. Biosystems A (2007) AmpFlSTR miniFiler ${ }^{\mathrm{TM}}$ PCR amplification kit user guide. Applied Biosystems, Foster City

30. Corporation P (2009) PowerPlex ESX 17 system technical manual. Promega Corporation, Madison

31. Biosystems A (2005) AmpFlSTR YFiler ${ }^{\mathrm{TM}}$ PCR amplification kit user guide. Applied Biosystems, Foster City

32. Parson W, Parsons TJ, Scheithauer R, Holland MM (1998) Population data for 101 Austrian Caucasian mitochondrial DNA d-loop sequences: application of mtDNA sequence analysis to a forensic case. Int J Legal Med 111:124-132

33. Zupanič Pajnič I, Balažic J, Komel R (2004) Sequence polymorphism of the mitochondrial DNA control region in the Slovenian population. Int J Legal Med 118:1-4

34. Bandelt HJ, Parson W (2008) Consistent treatment of length variants in the human mtDNA control region: a reappraisal. Int $\mathrm{J}$ Legal Med 122:11-21

35. Anderson S, Bankier AT, Barrell BG (1981) Sequence and organization of the human mitochondrial genome. Nature 290:457-465

36. Brenner CH (2007) DNA-VIEW 2007 user guide. Oakland

37. Zupanič I, Balažic J, Komel R (1998) Analysis of nine short tandem repeat (STR) loci in the Slovenian population. Int J Legal Med 111:248-250

38. Zupanič Pajnič I, Šterlinko H, Balažic J, Komel R (2001) Parentage testing with 14 STR loci and population data for 5 STRs in the Slovenian population. Int J Legal Med 114:178-180

39. Brenner CH, Weir BS (2003) Issues and strategies in the DNA identification of World Trade Center victims. Theor Popul Biol 63:173-178

40. Gusmao L, Butler JM, Carracedo A, Gill P, Kayser M, Mayr WR, Morling N, Prinz M, Roewer L, Tyler-Smith C, Schneider PM (2006) DNA commission of the international society of forensic genetics (ISFG): an update of the recommendations on the use of Y STRs in the forensic analysis. Int J Legal Med 120:191-200
41. Balding DJ, Nichols RA (1994) DNA profile match probability calculation: how to allow for population stratification, relatedness, database selection and single bands. Forensic Sci Int 64:125-140

42. Walsh B, Redd AJ, Hammer MF (2008) Joint match probabilities for $\mathrm{Y}$ chromosomal and autosomal markers. Forensic Sci Int 174:234-238

43. Willuweit S, Roewer L (2007) Y chromosome haplotype reference database (YHRD): update. Forensic Sci Int: Genetics 1:83-87

44. Parson W, Dür A (2007) EMPOP - a forensic mtDNA database. Forensic Sci Int: Genetics 1:88-92

45. Castella V, Dimo-Simonin N, Brandt-Casadevall C, Robinson N, Sougy M, Taroni F, Mangin P (2006) Forensic identification of urine sample: a comparison between nuclear and mitochondrial DNA markers. Int J Legal Med 120:67-72

46. Prinz M, Carracedo A, Mayr WR, Morling N, Parsons TJ, Sajantila A, Scheithauer R, Schmitter H, Schneider PM (2007) DNA Commission of the International Society for Forensic Genetics (ISFG): recommendations regarding the role of forensic genetics for disaster victims identification (DVI). Forensic Sci Int: Genetics 1:3-12

47. Nagy M, Otremba P, Krüger C, Bergner-Greiner S, Anders P, Henske B, Prinz M, Roewer L (2005) Optimization and validation of a fully automated silica-coated magnetic beads technology in forensics. Forensic Sci Int 152:13-22

48. Montpetit SA, Fitch IT, O'Donnell PT (2005) A simple automated instrument for DNA extraction in forensic casework. J Forensic Sci 50:555-563

49. Valgren C, Wester S, Hansson O (2008) A comparison of three automated DNA purification methods in forensic casework. Forensic Sci Int: Genetics Supplement Series 1:76-77

50. Kishore R, Hardy WR, Anderson VJ, Sanchez NA, Buoncristiani MR (2006) Optimization of DNA extraction from low-yield and degraded samples using the biorobot EZ1 and biorobot M48. J Forensic Sci 51:1055-1061

51. Gill P, Brenner CH, Buckleton JS, Carracedo A, Krawczak M, Mayr WR, Morling N, Prinz M, Schneider PM, Weir BS (2006) DNA commission of the International Society of Forensic Genetics: recommendations on the interpretation of mixtures. Forensic Sci Int 160:90-101

52. Budowle B, Eisenberg AJ, Dall A (2009) Validity of low copy number typing and applications to forensic science. Croat Med J 50:207-217 